TOURISM AND RECREATION

\title{
THE STUDY ABOUT GASTRONOMIC TOURISM AND GASTRONOMIC TOURISTS ISSUES
}

\author{
Tsatava Dalila, Ivane Javakhishvili Tbilisi State University Doctoral Student, TSU Tourism research \\ Centre Lecturer, Georgian Institute of Public Affairs (GIPA) Business Faculty Lecturer, President \\ Gastronomic Association of Georgia, Tbilisi, Georgia
}

\section{DOI: https://doi.org/10.31435/rsglobal_conf/25052021/7564}

\begin{abstract}
Introduction and Goal. The process of globalization has shifted the world and a lot of things are changing in the tourism field as well, especially in gastronomic tourism. The food is modifying and the trapeze culture, rituals and attitudes that are one of the characteristics of the nation's identity, are facing extinction. The majority of nations are constantly trying to use the natural, historical and cultural resources to maintain their identity. In this context, it is important to successfully develop the gastronomic tourism capabilities. This process is linked to the recent "gastronomic boom". Based on the topic's relevance, we have tried describe the concept of gastronomic tourism and role of gastronomic tourist in the development of country's economy and culture.

Theoretical and methodological basis of the research. The theoretical and methodological basis of this research are the contemporary Georgian and foreign scientific works on gastronomic tourism issues, expert evaluations, materials of international conferences dedicated to gastronomic tourism issues, historical and other sources.

Results and Implications. Based on the research we have determined the concept of gastronomic tourism with its various forms. The reflexive moment which is one of the most important points in this area, is very evolving, so the scientific part should show more activity towards the topic of tourism, economics and culture.

Conclusions. Understanding the gastronomic tourism as an important tourism business and the study of current events in the global world will help to develop gastronomic culture, maintain the identity of the nation, promote gastronomic tourism and enhance the economy of Georgia
\end{abstract}

Keywords: Gastronomic Tourism, Gastronomic Tourist, Gastronomic Culture, Trapeza - The process of eating meals.

Introduction. It can be said that the phenomenon referred to as gstronomic or sometimes as culinary tourism takes its roots in the deep past when the merchants would travel to get access to spices, medical plants, deserts, wine, and drinks.

In the recent world, globalisation has almost tackled all these issues. One can buy the product produced in any part of the world in the local supermarket. "McDonaldisation" has turned the trapeze into somewhat unified and identical thing. Nevertheless, the majority of tourists go into gastronomic tours with an intention to get a taste of national cuisine and get familiar with the nation's authentic tastes at the very places where some dishes and drinks were originated from and still are prepared following the old ways/techniques. That is why World Tourism Organisation (UNWTO) considers gastronomic/culinary tours to be more and more increasing tendency. The tourist when traveling to a country, naturally still gets familiar with this country's cuisine, gastronomic culture and it plays an important role in forming an idea about the country and its nation.

Good and high-quality national cuisine is precisely a defining factor for the effectiveness and popularity of gastronomic tourism.

About the definition. The concept "culinary tourism" was first introducted in 1998 by Lucy Long - a professor at National Culture Department in Bowling Green State University, Ohio State, USA. In order to express her idea of how people perceive different cultures through the food and trapeze culture, she noted: "I define culinary tourism as the intentional, exploratory participation in the foodways of an other - participation including the consumption, preparation, and presentation of a fooditem, cuisine, meal system, or eating style considered to belong to a culinary system not one's own. This definition highlights the importance of an individual as active participant in the process of acquiring the touristic experience, since the food, as part of this experience causes the esthetic reaction in him". (Long 2004:20-21). ${ }^{1}$

1 "The term "foodways" suggests that food is a new work of activities and systems - physical, social (communicative), cultural, economic, spiritual, and aesthetic" (Long 2004:23) 
Intensive and public discussions about gastronomic tourism as a new tendency began in 2001 when Erik Wolf, renowned American scientist, economist, anthropologist, and writer, founder of International Culinary Tourism Association in 2003 (ICTA), presented the first paper on culinary tourism concept. Later, this concept in the form of research was presented in his book where he described the increasing tendency of culinary tourism and its importance. The manifest of the World Food Travel Association (WFTA) expresses well the ability of the human to get to know the culture and history of the country, propensity, and habits of the nation through the eating culture. "Food - this is the quintessence of the nation's character and history"1.

Analysis of the current state.

International Institute of Gastronomy, Culture, Arts and Tourism (IGCAT) was founded in Brussels in 2012 and it oversees educational and scientific programs. ${ }^{2}$ The World Food Travel Association (WFTA) - the non-governmental organization is also an influential entity in this field. ${ }^{3}$

French, Mexican, Japanese cuisines together with the Mediterranean Sea countries' meal system are enlisted on United Nations Educational, Scientific, and Cultural Organization's (UNESCO) intangible cultural list. Also, each year UNESCO conducts research to reveal the best gastronomic city. The city of Popayán in Columbia, Chengdu - one of the popular centers of the Sichuan kitchens in China, Östersund in Sweden and Khatai in Turkey are all part of this list.

So, gastronomic tourism is becoming the best communication tool and a big business. Nowadays this term has already become an important expression of touristic products all over the world. It is worth noting that wine and beer thematic tours also form a part of this term. These tours help us perceive the culture of the vine, wine, and various drinks of different countries. As representatives of this business and culture are assuming this niche of tourism will become the prerequisite of many advantages for the future.

Firstly, it should be noted that food and drinks are the very first component during travel for any tourist, especially if the tour is about the national cuisine. Later, it becomes an important motivational factor to visit a certain country and get yourself familiar with the culture and other values along with the national cuisine. Gastronomic tourism gives the country an opportunity to introduce tangible and intangible values, rituals, traditions, folklore, music, the way of life, production of ecologically clean products, national, unique technological processes to the tourists locally, in the authentic situation. Additionally, one important fact should be pointed out - national cuisine gives the tourist a chance to actually participate in the preparation of the national, unique dishes. For this very reason, many tour operators make the degustations, culinary masterclasses and so on part of the tours. It is also noteworthy that these tours are often not seasonal and can be arranged anytime throughout the year. It is as well important if a gastronomic tour coincides with a festival, national celebration, or a big feast.

The above mentioned definition by Lucy Logan well exhibits the function that the notion gastronomic tourism has. The terms "culinary tourism", "food tourism" and so on are also used nowadays. According to Erik Wolf, this notion is very easy to define as the memorable dish during your travels creates experience and a feeling of uniqueness. ("The pursuit and enjoyment of unique and memorable food and drink experiences, both far and near." $)^{4}$

In the scientific circles of the post-soviet countries, this topic is becoming newsworthy from the economic as well as cultural, historical, and business standpoints. Within the scientific community, gastronomic tourism is defined as the factor for recognizing a nation's history, its diversity, and the whole palette of its traditions. "In the first place, gastronomic tourism is the tool for understanding peoples' mentality, century old traditions and the national soul with the help of food preparation and consumption culture. The gastronomic tour is a palette, tool that the tourist can use to draw up his viewpoints on the country. The food brings the secrets of the nations' souls to the light, helps us to understand their mentality." 5

However, it is interesting who is a gastronomic/food tourist and what type of people are they? What type of gastronomic tours do they choose?

\footnotetext{
${ }^{2}$ Retrieved from https://www.worldfoodtravel.org/cpages/what-is-food-tourism (02.02.2018)

${ }^{2}$ Retrieved from https://igcat.org/about/igcats-story/ (02.02.2018)

${ }^{3}$ Retrieved from www.worldfoodtravel.org/cpages/home (05.02.2018)

${ }^{4}$ Erik Wolf, Executive Director, World Food Travel Association, (2003). https://www.worldfoodtravel.org/cpages/whatis-food-tourism

5 Сохань, И.В. Особенности русской гастрономической культуры / И.В. Сохань // Вестник Томского государственного университета, 2011. - № 347. - С. 61-68.
} 
Gastronomic tourists are the people who can travel quite long distances to expand their gastronomic interests. We are not talking about people who love to eat, but the gourmets, history researchers, anthropologists, and representatives of different fields. Gastronomic tourists are many times people with a long travel history and can revisit a specific country just to learn about it from the gastronomic standpoint. Thus, it would be proper to say that everybody in the Ministry of Economy or Tourism Department has to understand that not every tourist goes to the museums or the exhibitions, but all of them try the national food of the country. Moreover, some do it on purpose to get familiar with this or that ethnoculture from this viewpoint, boom of this approach is in $21^{\text {st }}$ century. Sightseeing only is no longer sufficient for modern tourists, as they try to "feel" the country. And, gastronomic tourists do this the best. Food precisely supports finding a way into the country's culture and feel that "other" not only on the intellectual but also on the feelings' level. Food is an important attribute of tourist's destination which fills up the tourist's impressions with feelings. Globalisation and access to everything, bringing the role and the importance of the food forward, made the tours more appealing, especially for gourmets, historians, and anthropologists. They study the roots of the dishes, interests of the nations, the environment, being, and traditions. All these can be felt only on spot.

Thus, more and more people choose the tours with the gastronomic purpose. Gastronomic tourist is the one whose motivating factor to get to know the country is the food and drinks, their history, ritualistic purpose. This is the person who on purpose chooses local authentic food and never opts for mass food chains.

Segmentation of gastronomic tourist and gastronomic tourism.

Holp and Sharplz (2003) distinguished the few segments of the gastronomic tourism, base of this segmentation was mainly the interest factor:

1. The main factor for being interested in gastronomic tourism is visiting and tasting at the restaurants, markets, and various food chains, wineries, breweries, local cheese or seafood places. This segment was named gastronomic (gourmet, food, culinary) tourism by the scientists.

2. The second category of tourists is comprised of people who in parallel to travelling in the country also want to take part in the culinary masterclasses, try national dishes, understand different components of the eating culture.

3. The third category of food tourists participating in the gastronomic tours are the people who show little interest in historic and cultural meaning of food, but are curious about agriculture of the country and the differences between living in the village and the city.

4. The fourth segment of the tourists are the people who are not interested in the gastronomic culture and consider food as part of the daily activity, however, the authentic tastes are important for them.

Thus, we can conclude that gastronomic tourist can be the gourmet tourists with a fine taste for the host country's cuisine or the tourist who enjoys unique dishes of the specific region, "which can be

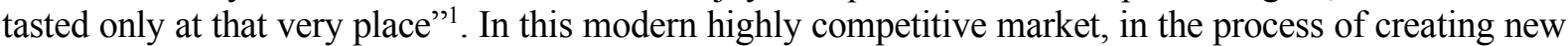
gastronomic experiences and adventures for the tourists it is very important to have culture, traditions and product attached to the specific tour and also, parallels to be made and connections to be found with the tourist's own culture. People working on the popularization of the gastronomic culture will have to spend more time to build the bridges between different spaces and regions. Besides familiarizing with the gastronomic culture, gastronomic tourism covers one more important component, which is gastronomic tourist observing the technological process of creating the authentic taste of the local dishes and participating in this process. Insight into nuances of the dishes prepared on spot by either locals or the renowned chefs is what the tourists pay money for. The tourist compares and realizes what are the radical differences or similarities between the representatives of that country or region and his own. Participating in the local festivals and the process of becoming part of the tradition or the culture makes the impressions of the tourist more vivid and this exactly is used by tourism as the big business. Gastronomic tourism forms a different viewpoint on the country, the tourists looks at the culture and landscape from a different angle starts to evaluate the specific region of this country differently.

McDonaldisation process all over the world which is associated with the globalisation aggravated glocalisation even more. On the contrary, people are more and more looking for new, special and exotic, not familiar. The food habit is as well very individual: somebody who likes fried potatoes, compares it to the grasshoppers tasted in the Missouri state, while those who love chicken, try tarantulas in Cambodia, and others make the comparison between beef and bats and etc. By arranging tours like this, the country can develop and bring forward different directions, since, for

\footnotetext{
${ }^{1}$ Tourism and Gastronomy - by Anne-Mette Hjalager and Greg Richards, Routledge (UK), 2001. (pages 21-35)
} 
instance, does not matter how gourmet the tourist is, he will not travel to France to just taste frog paws or the same tourist will not visit Cambodia to eat snake soup and blood or go to Georgia for khachapuri tasting only. These type of tours are also discussed in the cultural perspective, along with the interest towards the food culture, tourist deepens the knowledge about the nation, becomes more tolerant. Developments in gastronomic tourism change the global social attitudes in people, who see widely the role of food and meals in the history of human development and future perspectives in the united world where every spiece needs food.

Thus, the most distinguishing feature of gastronomic tourism is that every country has the ability to develop this direction. Gastronomic tourism is not seasonal and moreover, the gastronomic tours can become part of any touristic route.

\section{Key possibilities for the development of gastronomic tourism and Georgia.}

We did a brief overview of gastronomic tourism and the term of gastronomic tourist, possibilities for development and driving sources of gastronomic tourism. Higher the competition gets between touristic destinations, local culture, its authenticity, finding the distinguishing factors becomes more important. Gastronomy's role in all this is high as it is considered to be the destination's image source. We can consider gastronomy to be one of the supplemental fields of hospitability industry as well as independent field of tourism. UNWTO made a very good distinction, according to them, "along with authentic, traditional, and/or innovative culinary experiences, Gastronomy Tourism is characterized by studying the food, drinks, food products and getting the tourist interested in the traditional cuisine. Over recent decades, gastronomy tourism has gone beyond the table setting and now includes all sectors of a destination's food and tourism chain - producers (agriculture, fishing, etc.), the tourism and hospitality sector (restaurants, specialised accommodation, gastronomic activity firms, etc.), the retail sector, the commerce sector (sale of products) and even the knowledge sector". ${ }^{1}$ Based on the research works of UNWTO, scientists differentiate between gastronomic tourism and food tourism, since they consider that gastronomic tourism is a wider term. "We must differentiate between the terms gastronomy and culinary - culinary looks at definite food preparing systems, methods, technique, the culture of fire, dishes, raw materials, and recipes. Gastronomy covers raw materials, food products, drinks, the mixture of traditions, eating culture, the culture of receiving and distributing food, food consecutiveness. Therefore, gastronomy is a wider term". ${ }^{2}$

It is known that food structure defines the tourist's day. Food makes up the biggest part of the impressions for the majority of tourists. Tasting the food unique to the destination place, as already noted, leaves a signal: "this can be tasted here only". However, globalisation has put this approach at risk, now when the "French Fries" can be found anywhere in the world and seasonal food is sold throughout the whole year, food and place get separated from each other. In the fast-changing culinary landscape, the forces of globalisation and glocalisation influence our eating habbits. The spread of the fast-food become a characteristic of cultural globalisation and was formulated into the term "McDonaldisation". Albeit, globalisation has its pros, homesick tourists find it very pleasing to come across the domestic brand in the different country.

Attaching gastronomy to specific regions and countries is a powerful tourism marketing tool. Researching and studying the local and regional food can become the reason for traveling and visiting different countries. Many countries and regions in the world started to put this idea/approach into practice and, they use gastronomy as a marketing tool and sell tourism at the expense of it. From this viewpoint, Georgian gastronomic culture is a very interesting phenomenon as the number of contrasting cuisines can be found consolidated in a small geographical area. Referring to original, diverse cuisine specific and unique to the regions of Georgia. Georgian traditional table ("Supra") with its toastmaster, the wine-pourer institute is worth highlighting separately. The customs that differentiate "Supras" at the funerals from the ones during the feast with all its rituals create an appealing environment for the tourist. Georgia is a new market in gastronomic tourism, and accordingly, this field can be developed well here. We face the big challenge, considering its geographical location, the country has a touristic potential and accordingly for the touristic country, culinary should stand at a reasonably good level. At first sight, our gastronomy is stagnated, however, not many agree with this opinion, changes are happening, but at a very slow speed and if one is not familiar with the field, it is hardly noticeable. Following the Georgian history, the big mark the Soviet Union left on the Georgian gastronomy is easy to notice. The Soviet period caused the degradation of this field, we got locked up in some vacuum, gustative features started to disappear and we reached the

\footnotetext{
${ }^{1}$ UNWTO https://www.e-unwto.org/doi/pdf/10.18111/9789284420957

2 Драчёва, У Л. Гастрономический туризм: 15 февраля 2018 г. https://cyberleninka.ru/article/n/gastronomicheskiyturizm-kak-populyarnoe-napravlenie-v-turisticheskoy-industrii
} 
point when the food was no longer a part of the culture, ethnos with the traditional aspect but it became the element of "satiety". Despite the fact that Georgia has great potential in gastronomic tourism, in reality, there is no strategy and plan for developing this field. This field is still an untapped market. Logically, it brings us to the question of what is the reason? They include common gastronomic problems in Georgia, little involvement from National Tourism Administration and little interest from the private sector.

Research findings and conclusion. We would like to point out common gastronomic problems from the above-listed issues since the latter needs to be solved in the first place to tackle the rest of the issues. Based on the findings of our research, we have summarized few thoughts:

- The study of the countries' restaurant businesses, their menus, the ways how national dishes are presented, and the quality of raw materials.

- The requirements and standards set to the restaurants should be very strict so that the tour operator can correctly choose the food place for the tourists.

- Institutions that deliver culinary masterclasses should be studied, the content and the quality to be examined. Certification of chefs, quality of raw materials, and authenticity have to be also examined as these institutions are the gastronomic guides, presenters of history, anthropology, culture. All this requires comprehensive knowledge and education.

- Tour operator who plans the gastronomic tour should have a thorough knowledge of the food place and know that they will be greeted with "gastronomy tour guide" with the proper knowledge as the reflexive part defines success.

- Government bodies should closely follow blogs about gastronomic tourism, TV programs, masterclasses, radio or press information which popularize national cuisine and try to provide the government support for such initiatives.

- It is worth noting that the gastronomic tourist is already an experienced gourmet or hobbyist degustation, thus, this category of clients should be treated delicately, even the attempt to trick them is set to fail from the very beginning. This type of people are familiar with the cuisine from the number of different countries and that is why they choose gastronomic tours. They are experienced and realize very well that you cannot feel the smell or the taste from the internet and invest in traveling which brings the income for the tour operator on one hand and image and strengthening the economy for the country on the other hand.

Thus, gastronomic tourism is a new topic not only for Georgia but the whole world, but it is a big component of a big business of tourism. Albeit, the reflexive part is poor, as the scientists do not conduct an in-depth study of the gastronomic culture, gastronomy as an individual topic of tourism. Nowadays, the interest is high, and more and more interdisciplinary subjects will be connected to this.

\section{REFERENCES}

1. Tourism and Gastronomy - by Anne-Mette Hjalager and Greg Richards, Routledge (UK), 2001. (245 pages)

2. Tourism and gastronomy (handwritten manual, 202 A4 page) - author Dalila Tsatava

3. Erik Wolf, Executive Director, World Food Travel Association, 2003). Retrieved from https://www.worldfoodtravel.org/cpages/what-is-food-tourism

4. Retrieved from www.worldfoodtravel.org/cpages/home

5. "The term "foodways" suggests that food is a new work of activities and systems - physical, social (communicative), cultural, economic, spiritual, and aesthetic" (Long 2004:23)

6. Retrieved from https://www.worldfoodtravel.org/cpages/what-is-food-tourism

7. Retrieved from http://www.dr-gerald-wetzel.de/assets/2015-01-kulinarischer-tourismus.pdf

8. Retrieved from http://kulinarischer-tourismus.de/

9. Retrieved from https://www.e-unwto.org/doi/pdf/10.18111/9789284420957

10. Драчёва, У. Л. Гастрономический туризм: $15 \quad$ февраля 2018 г. $\quad$ Retrieved from https:/cyberleninka.ru/article/n/gastronomicheskiy-turizm-kak-populyarnoe-napravlenie-v-turisticheskoy-industrii

11. М. В. Капкан, Л. С. Лихачева (2008). Гастрономическая культура: понятие, функции, факторы формирования. Известия Уральского государственного университета. Сер. 2, Гуманитарные науки. 2008. № 55, вып. 15. - С. 34-43.

12. Сохань, И.В. Особенности русской гастрономической культуры / И.В.Сохань // Вестник Томского государственного университета, 2011. - № 347. - С. 61-68.

13. Retrieved from www.worldfoodtravel.org/cpages/home (05.02.2018) 